\title{
Neoselachians from the Danian (early Paleocene) of Denmark
}

\author{
Jan S. Adolfssen and David J. Ward \\ Acta Palaeontologica Polonica 60 (2), 2015: 313-338 doi: http://dx.doi.org/10.4202/app.2012.0123
}

A diverse elasmobranch fauna was collected from the early Danian Rødvig Formation and the early to middle Danian Stevns Klint Formation at Stevns Klint and from the middle Danian Faxe Formation at Faxe, Denmark. Teeth from 27 species of sharks are described including the earliest records of Chlamydoselachus and Heptranchias howelli from Europe. The fauna collected at the Faxe quarry is rich in large species of shark including Sphenodus lundgreni and Cretalamna appendiculata and includes no fewer than four species of Hexanchiformes. The species collected yield an interesting insight into shark diversity in the Boreal Sea during the earliest Paleogene. The early Danian fauna recorded from the Cerithium Limestone represents an impoverished Maastrichtian fauna, whereas the fauna found in the slightly younger bryozoan limestone is representative of a pronounced cold water fauna. Several species that hitherto have only been known from the Late Cretaceous have been identified, clearly indicating that the K-T boundary was not the end of the Cretaceous fauna; it lingered and survived into the early Danian.

Key words: Chondrichthyes, Faxe Formation, Cerithium Limestone, Danian, Paleocene, Denmark.

Jan S. Adolfssen [janadolfssen@yahoo.com], Natural History Museum of Denmark, Østervoldgade 5-7, DK-1350 Copenhagen, Denmark; David. J. Ward [djw@nhm.ac.uk], Department of Earth Sciences, The Natural History Museum, London, SW7 5BD, United Kingdom.

This is an open-access article distributed under the terms of the Creative Commons Attribution License (for details please see creativecommons.org), which permits unrestricted use, distribution, and reproduction in any medium, provided the original author and source are credited. 
